\section{(6) OPEN ACCESS}

CASE REPORT

\title{
Respiration driven excessive sinus tachycardia treated with clonidine
}

\author{
Matthew Emile Li Kam Wa, ${ }^{1}$ Patricia Taraborrelli, ${ }^{1}$ Sajad Hayat, ${ }^{2}$ Phang Boon Lim
}

'Department of Cardiology, Imperial College Healthcare NHS Trust, London, UK ${ }^{2}$ Department of Cardiology, University Hospitals Coventry and Warwickshire NHS Trust, Coventry, UK

\section{Correspondence to} Dr Phang Boon Lim, p.b.lim@imperial.ac.uk

Accepted 18 December 2016

\section{SUMMARY}

A 26-year-old man presented to our syncope service with debilitating daily palpitations, shortness of breath, presyncope and syncope following a severe viral respiratory illness 4 years previously. Mobitz type II block had previously been identified, leading to a permanent pacemaker and no further episodes of frank syncope. Transthoracic echocardiography, electophysiological study and repeated urine metanepherines were normal. His palpitations and presyncope were reproducible on deep inspiration, coughing, isometric hand exercise and passive leg raises. We demonstrated rapid increases in heart rate with no change in morphology on his 12 lead ECG. His symptoms were resistant to fludrocortisone, flecainide, $\beta$ blockers and ivabradine. Initiation of clonidine in combination with ivabradine led to rapid resolution of his symptoms. We suggest that an excessive respiratory sinus arrhythmia was responsible for his symptoms and achieved an excellent response with the centrally acting sympatholytic clonidine, where previous peripherally acting treatments had failed.

\section{BACKGROUND}

Palpitations, presyncope and syncope are potentially debilitating symptoms that can have a significant functional impact on patients. We present an unusual case of these symptoms that were inducible with a simple deep breath, which after extensive investigation was refractory to traditional treatments. These were successfully treated with the centrally acting sympatholytic, clonidine.

\section{CASE PRESENTATION}

A 26-year-old man presented to our tertiary syncope centre following previous investigation and treatment elsewhere with daily palpitations, shortness of breath, sweating, presyncope and syncope. Onset of his symptoms followed several weeks of a severe cough and viral respiratory illness 4 years previously. His symptoms were induced on deep respiration or on minimal exertion and showed a diurnal variation, being more pronounced in the early morning and evening, and were not reproducibly related to postural changes. He had over 30 attendances in a year to his local emergency department and had been forced to stop work due to his debilitating symptoms.

To cite: Li Kam Wa ME, Taraborrelli P, Hayat S, et al. BMJ Case Rep Published online: [please include Day Month Year] doi:10.1136/ bcr-2016-216818

\section{INVESTIGATIONS}

Transthoracic echocardiography was normal, and an electrophysiological study showed suprahisian block with Mobitz type II block interval. There was no evidence of dual AV node physiology, accessory pathway or inducible supraventricular tachycardia.

A subsequent permanent pacemaker led to no further episodes of frank syncope. However his ongoing debilitating exertional and respiratorydriven palpitations with presyncope remained. Conservative measures including increased fluid intake and compression stockings had no effect. Trials of medication including fludrocortisone, flecainide, $\beta$ blockers and ivabradine were either not tolerated or had no significant effect on his symptoms.

During a simple active stand over $3 \mathrm{~min}$, his heart rate increased from 90 to $112 \mathrm{bpm}$. His 12 lead ECG at $30^{\circ}$ head-up tilt is shown in figure 1 with an initial heart rate of $91 \mathrm{bpm}$. Following deep inspiration (arrow), his heart rate rapidly increased to $150 \mathrm{bpm}$ within $6 \mathrm{~s}$ with no change in $\mathrm{P}$ wave or QRS morphology. Maximal heart rate with deep inspiration alone was $167 \mathrm{bpm}$. Coughing, isometric hand exercise and passive leg raises all led to similar increases in heart rate and reproduction of symptoms despite taking ivabradine $5 \mathrm{mg}$ two times a day.

\section{OUTCOME AND FOLLOW-UP}

He was started on clonidine $0.1 \mathrm{mg}$ two times a day in combination with ivabradine. This led to a rapid resolution of his respiratory-induced palpitations at rest with no further admissions to hospital. Notably, his quality of life improved sufficiently to allow him to return to work and complete his university degree. Although initially troubled by side effects of drowsiness and fatigue leading to temporary discontinuation of treatment, he has since been re-established on therapy and continues to see benefits from clonidine over 2 years later.

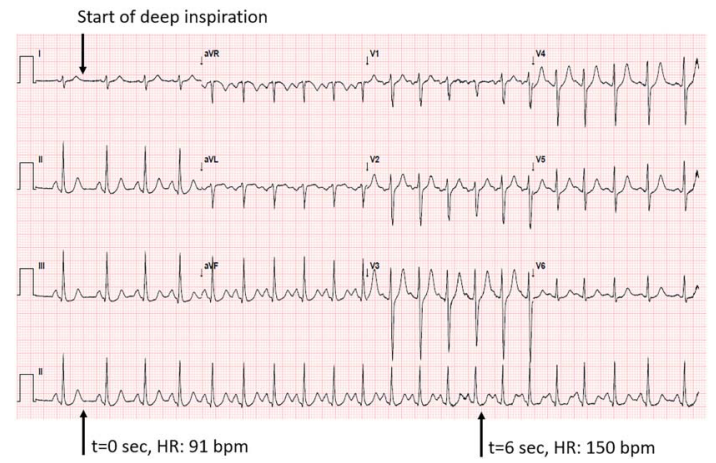

Figure 112 lead ECG at $30^{\circ}$ head up tilt, initially at $91 \mathrm{bpm}$. Deep inspiration (arrows, left) is followed by an increase in heart rate to $150 \mathrm{bpm}$ within seconds. 


\section{DISCUSSION}

Variation in heart rate with the respiratory cycle is a well described, but not yet a fully understood phenomenon known as respiratory sinus arrhythmia. Through a predominantly vagally mediated response, the normal response to inspiration is an increase in heart rate. Suggested mechanisms for this response include the activation of pulmonary stretch receptors, increased firing of atrial and arterial baroreceptors and modulation by central respiratory drive. ${ }^{1}$

Treatments acting on the efferent end points of this pathway alone, such as ivabradine and $\beta$ blockers, failed to show any improvement. However, we were able to achieve an excellent response by combining these therapies with the centrally acting clonidine.

\section{Patient's perspective}

Email from the patient (31 October 2016): This condition is far from what I would wish on anyone. However, I have managed to cope with it, as much as can be expected. I still am on clonidine and have been titrated down to $50 \mu \mathrm{g}$ three times a day. This is one of the tablets that I felt helps me as it stops the forceful contractions of my heart. I find that exercise is still a very big no-no for me. However, I am managing to do everyday things like go to university. Since I last came down to London, this condition has flourished and affected my sleep. It seems like I am using medication to compensate for a switch from parasympathetic to sympathetic state and the reverse (especially at night). Clonidine is one of the tablets that has the least effect on my blood pressure but stops the 'adrenal storms' I usually get. To be honest, I find that the medication I am on only suppresses symptoms and I normally have to prepare for a couple of days of breakthrough symptoms that last longer than if I was not on medication. However, I would prefer to have it this way as it allows me to gain a bit of control over my life. I thank your team for everything they did as you were $100 \%$ right in your diagnosis.

\section{Learning points}

- Respiratory sinus arrhythmia remains a not yet fully understood mechanism where the respiratory cycle leads to variations in the heart rate in sinus rhythm.

- While an exaggerated respiratory sinus arrhythmia is commonly seen during tilt testing, such a marked symptomatic sinus tachycardia following a single deep breath proved difficult to manage.

- When traditional peripherally acting treatments for palpitations such as $\beta$ blockers and ivabradine have failed, we have shown an excellent response with the addition of the centrally acting agent clonidine.

Contributors MELKW authored the manuscript. PT, SH and PBL were responsible for the clinical management of the patient in this case report and coauthored the manuscript.

Funding This work is supported by the National Institute for Health Research Biomedical Research Centre based at Imperial College Healthcare NHS Trust and Imperial College London.

Competing interests None declared.

\section{Patient consent Obtained.}

Provenance and peer review Not commissioned; externally peer reviewed.

Open Access This is an Open Access article distributed in accordance with the Creative Commons Attribution Non Commercial (CC BY-NC 4.0) license, which permits others to distribute, remix, adapt, build upon this work non-commercially, and license their derivative works on different terms, provided the original work is properly cited and the use is non-commercial. See: http://creativecommons.org/ licenses/by-nc/4.0/

\section{REFERENCE}

1 Grossman P, Taylor EW. Toward understanding respiratory arrhythmia: relations to cardiac vagal tone, evolution and biobehavioral functions. Biol Psychol 2007;74:263-85.

Copyright 2017 BMJ Publishing Group. All rights reserved. For permission to reuse any of this content visit

http://group.bmj.com/group/rights-licensing/permissions.

BMJ Case Report Fellows may re-use this article for personal use and teaching without any further permission.

Become a Fellow of BMJ Case Reports today and you can:

- Submit as many cases as you like

- Enjoy fast sympathetic peer review and rapid publication of accepted articles

- Access all the published articles

- Re-use any of the published material for personal use and teaching without further permission

For information on Institutional Fellowships contact consortiasales@bmjgroup.com

Visit casereports.bmj.com for more articles like this and to become a Fellow 